\title{
Pendampingan Produksi Film Sebagai Bentuk Pelestarian Kesenian Tradisi Di Desa Sumber Muntilan
}

\author{
Budi Dwi Arifianto1*, Citra Dewi Utami2*, dan Zein Muffarih Muktaf3 \\ ${ }^{1,3}$ Program Studi Ilmu Komunikasi, Fakultas IImu Sosial dan ilmu politik, Universitas Muhammadiyah Yogyakarta \\ ${ }^{2}$ Institut Seni Indonesia Surakarta, J. Ringroad Mojosongo, Surakarta, Jawa Tengah 57127 telp (0271) 647658 \\ Email: budi_arifianto@umy.ac.id \\ DOI: 10.18196/ppm.31.146
}

\begin{abstract}
Abstrak
Seni tradisional adalah bagian dari kekayaan bangsa Indonesia yang wajib untuk dilestarikan. Nilai-nilai kearifan lokal yang terkandung di dalamnya berfungsi mendinamisasi masyarakat daerahnya. Generasi muda adalah pewaris yang diharapkan memahami dan berperan aktif menjaganya. Teknologi pembuatan film yang berkembang secara masif menggerakkan semangat anak muda membuat film, bukan hanya sebagai penonton. Pengalihwahanaan seni tradisional menjadi bentuk film merupakan strategi untuk mendekatkan dan menumbuhkan kecintaan anak muda terhadap seni tradisi. Mitra PPM ini adalah Komunitas Film Desa Ant Black dan Sanggar Ketoprak Santhi Aji yang berada di Desa Sumber, Kecamatan Dukun, Kabupaten Magelang. Program ini merupakan keberlanjutan dari program pelatihan pengelolaan Ndeso Film Festival (NFF) 2019 yang mampu memantik semangat produksi film para pemudanya. Proses produksi yang kurang terencana mengakibatkan kelelahan kru dan pemainnya, sehingga waktu produksi menjadi molor dan belum dihasilkannya karya film dengan baik. Oleh sebab itulah program pendampingan ini dibutuhkan oleh masyarakat. Metode yang dipilih dalam program PPM ini adalah 1) Dengar pendapat dan diskusi; 2) Pelatihan dan workshop produksi; 3) Pendampingan proses pascaproduksi; dan 4) Pemberian hibah peralatan penyuntingan digital. Hasil yang dicapai dari program ini adalah meningkatnya pengetahuan dan keterampilan mitra dalam memproduksi film serta penambahan jumlah karya yang dihasilkan berupa film pendek berjudul Ledhek Bariyem.

Kata Kunci: film, ketoprak, Ndeso Film Festival
\end{abstract}

\section{Pendahuluan}

Perkembangan teknologi dan semakin terbukanya arus informasi menjadi tantangan bagi kesenian ketoprak untuk dapat bertahan. Para pelaku dan penikmat ketoprak yang didominasi oleh orang-orang tua memunculkan persoalan terkait dengan kelestarian kesenian tersebut di masa depan. Generasi muda adalah pewaris yang diharapkan memahami nilai-nilai kearifan lokal yang terkandung di dalamnya dan berperan aktif menjaganya. Pelestarian tradisi dapat dilakukan melalui adaptasi kemasan atau pengalihwahanaan (Utami, 2010: 12). Sehingga dibutuhkan upaya nyata untuk mewujudkan hal tersebut.

Pada era digital saat ini, film yang merupakan budaya kontemporer, dinilai efektif dalam mempersuasi khalayak sasaran komunikasinya. Teknologi yang tergenggam di tangan anak muda hendaknya dapat dimanfaatkan untuk membuat film yang bermanfaat. Kondisi tersebut membutuhkan bantuan agar potensi yang ada mengarah kepada hasil yang positif. Salah satunya melalui program Pengabdian Pada Masyarakat (PPM) yang diinisiasi oleh institusi pendidikan tinggi.

Pengalihwahanaan seni tradisional menjadi bentuk film merupakan strategi untuk mendekatkan dan menumbuhkan kecintaan anak muda terhadap seni tradisi. Film menjadi lokomotif ekonomi kreatif Indonesia dapat terwujud melalui karya yang dihasilkan. Mitra Pengabdian kepada masyarakat ini adalah Komunitas Film Desa ANT BLACK dan Sanggar Ketoprak Santhi Aji yang berada di Desa Sumber, Kecamatan Dukun, Kabupaten Magelang. Lokasi ini berjarak sekitar $38 \mathrm{~km}$ dari kampus Universitas Muhammadiyah Yogyakarta. Sebelumnya telah terlaksana program pelatihan pengelolaan festival film bertajuk Ndeso Film Festival (NFF) 2019 yang mampu memantik semangat produksi film bagi para pemudanya. 
Keberlanjutan dari kegiatan tersebut, mereka berinisiatif membuat film, namun belum berhasil. Persiapan dan proses produksi yang kurang terencana mengakibatkan kelelahan kru dan pemainnya, sehingga waktu produksi menjadi molor dan belum berhasil dengan baik. Sehingga pada gilirannya peningkatan keterampilan membuat film merupakan kemampuan yang penting untuk dikuasai anak muda daerah pedesaan sebagai upaya pemberdayaan masyarakat yang berkelanjutan.

Program ini merupakan lanjutan dari program PPM sebelumnya yang didanai oleh Universitas Muhammadiyah Yogyakarta. Berdasarkan hasil evaluasi dari keberlanjutan program, dapat diketahui permasalahan mitra adalah sebagai berikut:

1. Minimnya pengetahuan tentang perbedaan karakteristik naskah ketoprak dan skenario film.

2. Minimnya kemampuan dalam mengelola produksi sebuah film.

3. Minimnya keterampilan penggunaan peralatan produksi film.

4. Belum dimilikinya peralatan penyuntingan film yang memadai.

Identifikasi masalah tersebut mendorong rancangan program PPM untuk fokus pada meningkatkan pengetahuan, keterampilan dan jumlah karya film pendek yang dihasilkan.

\section{Metode}

Program PPM mengedepankan konsep pembangunan yang berpusat pada rakyat (People Centred Development) yang dinyatakan oleh Korten (2002), memandang inisiatif rakyat sebagai sumber daya pembangunan paling utama dan memandang kesejahteraan spiritual dan material sebagai hal yang ingin dicapai. Pemberdayaan masyarakat bertujuan agar masyarakat mampu mengidentifikasi dan menganalisis permasalahannya sendiri sehingga mampu merumuskan alternatif pemecahan masalah yang dihadapi. Rancangan program kegiatan dijalankan melalui beberapa tahap, yaitu:

1. Penilaian awal permasalahan untuk bersama-sama menemukan solusi yang tepat dengan cara dengar pendapat.

2. Pelatihan manajemen produksi film untuk dapat mengelola sebuah produksi film dengan baik dan optimal.

3. Pelatihan penggunaan peralatan produksi film untuk meningkatkan keterampilan penggunaan peralatan produksi film.

4. Pendampingan selama proses produksi sebagai bentuk pengarahan dan evaluasi selama proses produksi.

5. Pemberian peralatan penyuntingan film untuk kegiatan memproduksi film yang berkelanjutan.

Gambaran iptek yang ditransfer dalam program PPM ini adalah pengetahuan, keterampilan, dan literasi film. Pelatihan yang diberikan adalah manajemen produksi, teknik sinematografi dasar, dan teknik dasar editing non-linier dengan software adobe premiere. Untuk meningkatkan produktivitas dan keberlanjutan dalam berkarya diberikan alat penyutingan audio visual.

\section{Hasil dan Pembahasan}

Ilmu pengetahuan dan teknologi yang ditransfer melalui program PPM ini berupa pengetahuan perencanaan, keterampilan dan literasi produksi film. Produksi film sebagai kegiatan pemberdayaan dapat dijalankan melalui tahapan ; pemetaan masalah, ide, pesan yang ingin disampaikan kepada khalayak, dampak yang ingin dicapai, pelibatan subjek, mengandung unsur keterbukaan dan dialogis dalam proses menyampaikan masalah atau solusi. Setelah itu baru diteruskan pada development, pra-produksi, produksi, pasca-produksi, dan distribusi. 
Film sebagai Pemberdayaan

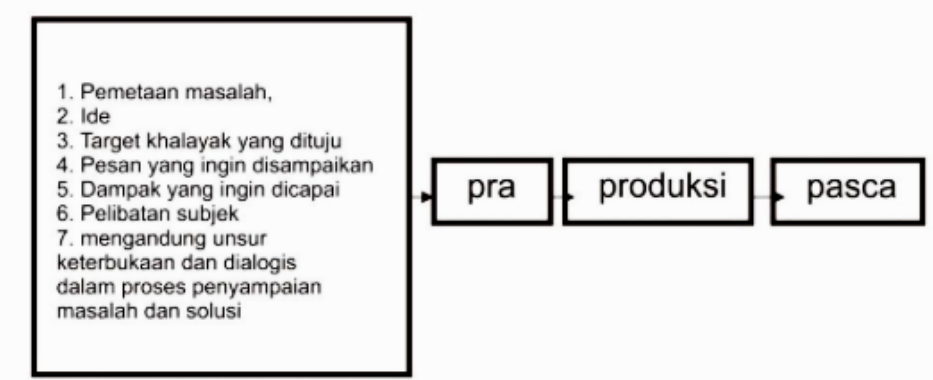

Gambar 01. Film sebagai Pemberdayaan (Sumber : Arifianto,2019)

Program PPM ini dilaksanakan pada bulan Desember 2019 sampai dengan bulan Agustus 2020. Penilaian awal permasalahan, kegiatan ini dilakukan melalui dengar pendapat dan diskusi dengan para anggota komunitas film desa serta pejabat pemerintahan Desa Sumber. Pertemuan dan FDG dilakukan di rumah Bapak Eko Kalisno selaku sekretaris desa sebanyak 3 kali. Kegiatan dengar pendapat ini bermanfaat untuk merumuskan ide menjadi sebuah skenario yang diadaptasi dari naskah pertunjukkan ketoprak. Proses ini biasa disebut sebagai tahap development. Potensi yang dimiliki oleh mitra telah melatarbelakangi ide gagasan yang dikembangkan menjadi skenario film. Potensi seni pertunjukkan yang dimiliki desa Sumber telah mampu memberikan kontribusi terhadap cerita serta para pemain ketoprak yang dapat diarahkan sebagai aktor dan aktris. Pemilihan cerita dikontekskan dengan kondisi yang terjadi di masyarakat saat ini. Isu politik sedang panas di masyarakat, sehingga mitra memilih cerita berjudul Ledhek Bariyem. Pemilihan Lurah merupakan pesta demokrasi di sebuah desa. Konflik yang dipicu oleh kegiatan tersebut diangkat dalam skenario yang dikembangkan. Naskah ketoprak yang sering dipentaskan tersebut penuh dengan unsur kearifan lokal bisa dinikmati dalam bentuk tayangan film.

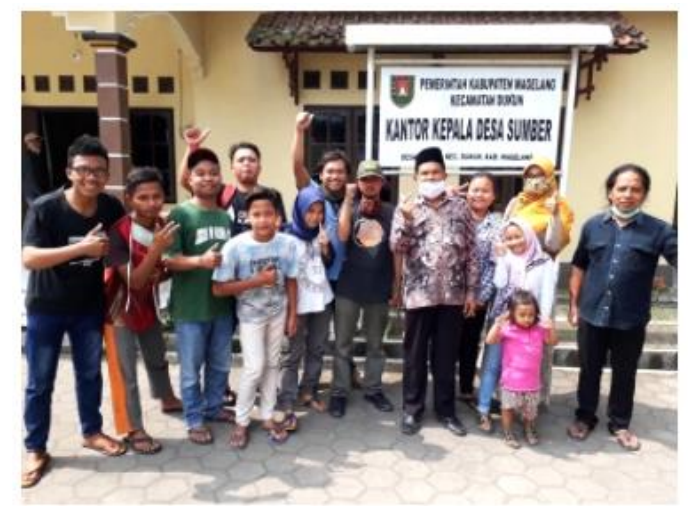

Gambar 02. Kegiatan Dengar Pendapat dan Diskusi

Kegiatan berikutnya adalah pelatihan manajemen produksi film. Kegiatan ini dilakukan pada tahap praproduksi. Secara teknis mereka sudah pernah membuat karya film tetapi masih kurang dalam pengelolaanya. Dalam workshop ini dijelaskan tentang deskripsi pekerjaan masing kru yang terlibat. Pengorganisasian kerja produksi film yang baik akan membawa hasil yang baik pula. Namun dalam kondisi berkomunitas, asas gotong royong tetap diutamakan. Pelatihan ini dilakukan secara paralel dengan membagi peserta sesuai minatnya. Kegiatan paralel yang lain adalah pelatihan penggunaan peralatan produksi film. Peningkatan keterampilan penggunaan peralatan produksi film sesuai dengan standar operation prosedur adalah tujuannya. Sejauh ini, pembelajaran yang didapat oleh mitra adalah berdasarkan pengalaman belajar sendiri atau otodidak, sehingga membutuhkan pelatihan untuk mengasah 
keterampilannya. Dalam kegiatan mengenalkan sistem peralatan kamera, lighting, sound, dan software editing.

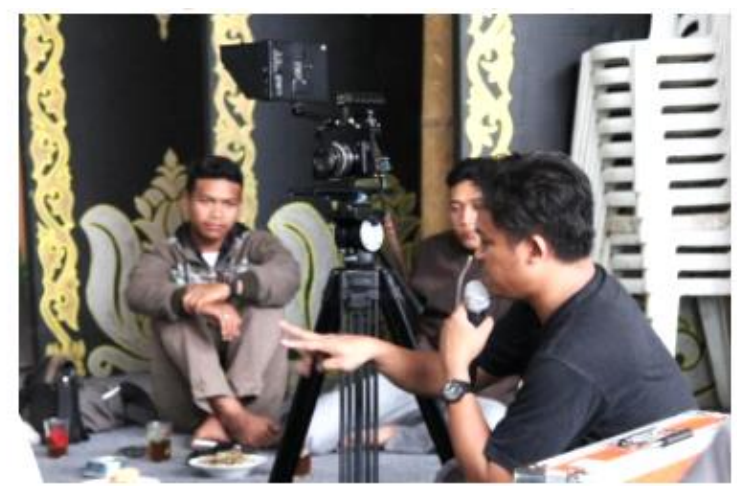

Gambar 03. Pelatihan Penggunaan Peralatan Sinematografi

Kegiatan ini dilakukan sebelum ada peraturan PSBB sehingga digelar secara luring. Hal tersebut patut disyukuri karena workshop keterampilan akan mengalami kendala jika dilakukan secara daring. Kebutuhan mitra atas saran dan masukan untuk dapat menghasilkan karya yang baik adalah penting guna menjaga semangat berkarya dan kualitas karya yang dihasilkan. Kegiatan pendampingan ini sebatas pemantauan apa yang sudah dikerjakan pada saat produksi. Produksi model komunitas ini tentunya berbeda dengan produksi secara profesional. Mereka membuat jadwal yang disesuaikan dengan kondisi dan kegiatan para kru dan pemainnya. Kebanyakan mereka adalah petani dan pekerja harian ada juga yang sekolah. Produksi ini memakan waktu 3 bulan dan dengan waktu produksi yang banyak mengambil hari-hari luang seperti Sabtu-Minggu atau di hari libur nasional.
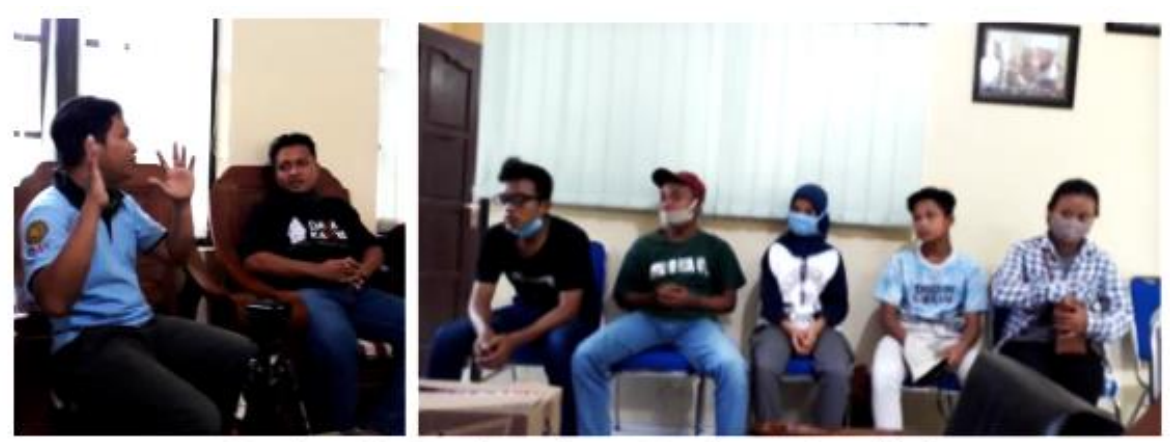

Gambar 04. Pendampingan Persiapan Produksi.

Pada pertengahan bulan Februari mulai merebak virus Corona di Indonesia dan peraturan pembatasan sosial diberlakukan dari pemerintah sehingga menjadi salah satu faktor penghambat proses produksi. Patut disyukuri karena pada bulan itu persentase produksi sudah menunjukkan $80 \%$ adegan sudah diambil.

Pemberian hibah peralatan penyuntingan digital diharapkan dapat memicu keberlanjutan dari PPM ini. Peralatan dapat dimanfaatkan untuk memproduksi film-film secara mandiri oleh mitra. 


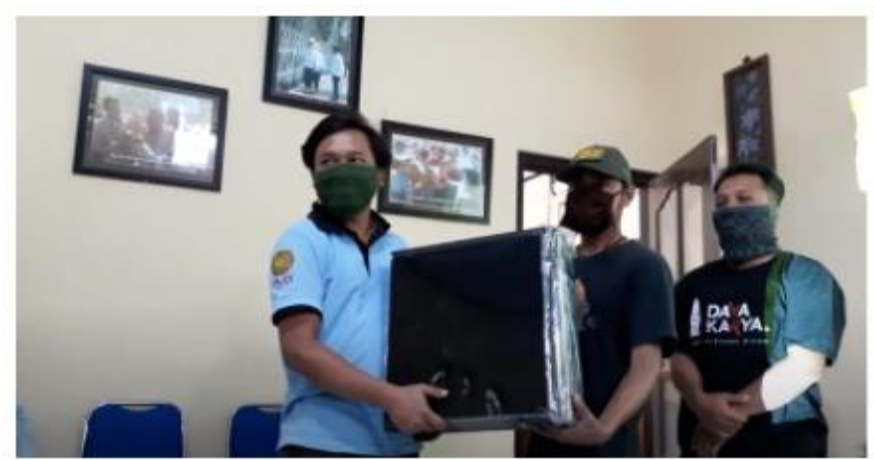

Gambar 05. Serah Terima Hibah Peralatan Editing

Pada masa pandemi menjadikan model pendampingan beralih menggunakan video conference. Aplikasi ZOOM dipilih karena memiliki fitur yang dibutuhkan seperti share screen dan recording meeting. Pada pertemuan daring tersebut tim PPM memberikan masukkan yang fokus pada alur cerita, kerapian editing, dan mixing audio.

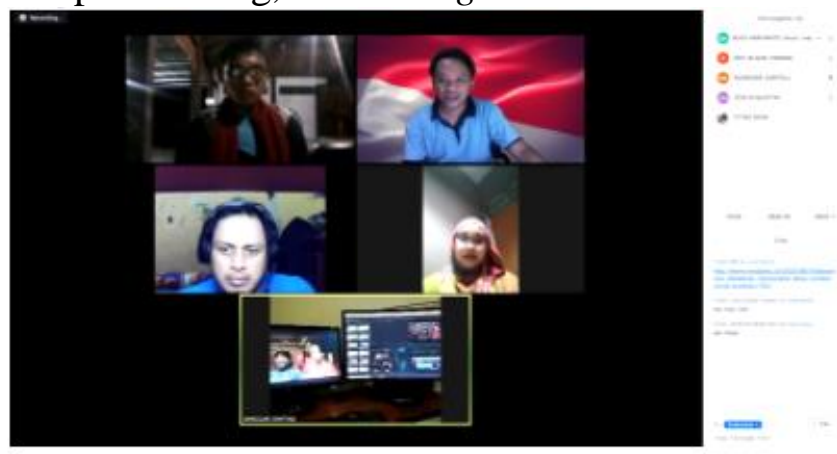

Gambar 06. Monitoring Daring

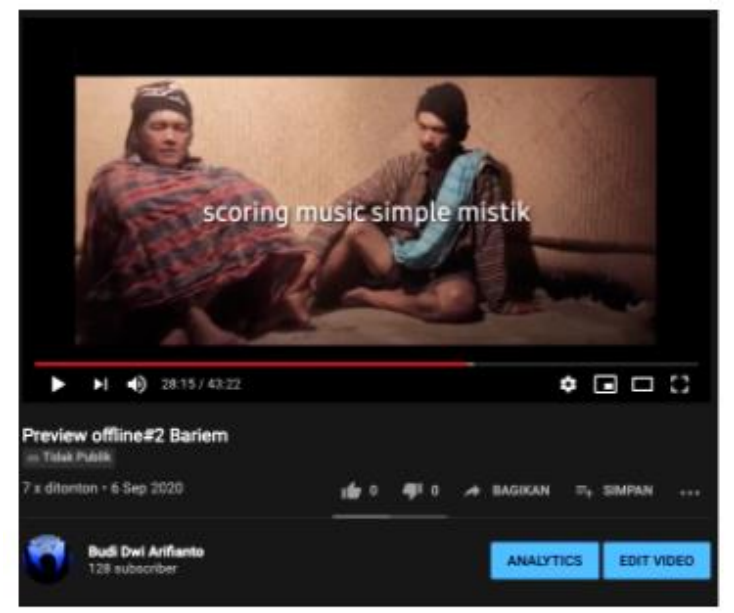

Gambar 07. Offline Editing Ledek Bariyem

Hasil editing offline diunggah melalui youtube dengan status unlisted agar dapat diakses oleh seluruh anggota tim PPM. Visual review dilaksanakan dengan cara talking head picture in picture. Untuk bisa melakukan ini dibutuhkan aplikasi OBS dan Youtube. 


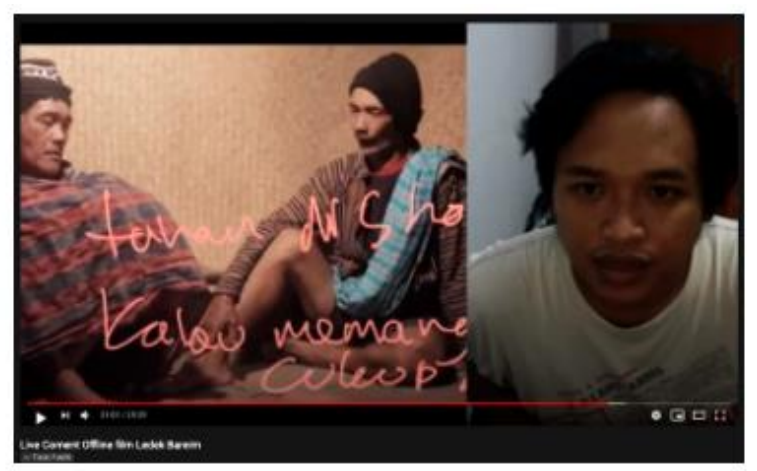

Gambar 08. Pendampingan Daring

Demikianlah pelaksanaan PPM yang menggabungkan sistem luring dan daring dijalankan.

\section{Simpulan}

Peningkatan keterampilan mitra dalam menjalankan rangkaian proses produksi film terbukti melalui kerja produksi film yang telah dijalankan. Kemampuan teknis penggunaan peralatan produksi film dan pendampingan produksi film telah memberikan pengalaman bagi mitra untuk dapat memproduksi film secara mandiri. Kolaborasi antara generasi muda pembuat film dan generasi tua pelaku seni tradisi yang ada di desa sumber terwujud melalui fasilitasi pelaksanaan PPM. Pemberian hibah peralatan berupa editing audio visual bisa menjadi modal untuk berkelanjutan kerja produksi film berikutnya. Film yang diangkat dari adaptasi naskah ketoprak sebagai wujud usaha pelestarian seni tradisi.

\section{Ucapan Terima Kasih}

Terima kasih kepada LP3M UMY yang telah memberikan dana pengabdian, sehingga PPM dapat terlaksana. Dan juga kepada bapak Eko Kalisno selaku sekretaris Desa sumber yang telah membantu memfasilitasi pelaksanaan kegiatan ini.

\section{Daftar Pustaka}

Budi Dwi Arifianto. 2019. Open Air Cinema Sebagai Ruang Komunikasi. Publisitas: Jurnal Penelitian Ilmu Sosial dan Politik. Volume 1 No. 11 September 2019.

Rasid Yunus. 2014. Nilai-Nilai Kearifan Lokal (Local Genius) Sebagai Penguat Karakter Bangsa (Studi Empiris Tentang Huyula. Yogyakarta: Deepublish.

Brown, Blain. 2012. Cinematography: Theory And Practice : image making for cinematographers and directors. Oxford : Focal Press.

Citra Dewi Utami. 2010. Film Dokumenter sebagai Media Pelestari Tradisi. Acintya: Jurnal Penelitian Seni Budaya. Volume 2 No. 1 Juni 2010.

Hasan Alwi. dkk. 2003. Tata Bahasa Baku Bahasa Indonesia (Edisi Ketiga). Jakarta: Balai Pustaka.

Korten, D. C. (2002). Menuju Abad Ke-21; Tindakan Sukarela dan Agenda Global. Jakarta: Yayasan Pustaka Obor Indonesia. 